\title{
БАНКОСТРАХОВАНИЕ И ПРОБЛЕМЫ ЕГО РАЗВИТИЯ В РОССИИ И ЗАРУБЕЖНЫХ СТРАНАХ
}

\begin{abstract}
Аннотация. Экономические кризисы и ухудшение макроэкономической ситуации негативным образом влияют на основные показатели банковской и страховой деятельности. В отечественной финансовой науке устойчиво преобладало мнение, что основная задача страхования заключается в сокращении рисков и минимизации возможных потерь в сфере социально-экономических отношений на основе финансовой защиты. Однако теоретические и практические исследования доказывают, что роль страхования значительно шире, а синергетический эффект от позитивных процессов на страховом и банковском рынках оказывают влияние на ускоренное и стабилизирующее развитие других секторов экономики. Взаимное проникновение банковского и страхового бизнеса последние десять лет было доминирующей тенденцией на финансовом рынке, что создало предпосылки рассмотрения и анализа такого явления как банкострахование. В статье рассматриваются подходы к определению термина «банкострахование». Показана практика применения и уровень развития банкострахования как в России, так и в зарубежных странах. Проводится анализ мирового рынка банкострахования и обозначены проблемы его развития.

Ключевые слова. Страхование; банкострахование; банки; страховые организации; кредитное страхование; экономический кризис.

Информация о статье. Дата поступления 31 марта 2015 г.; дата принятия к печати 14 апреля 2015 г.; дата онлайн-размещения 5 мая 2015 г.
\end{abstract}

Ye. G. Sarsenova

Baikal State University of Economics and Law, Irkutsk, Russian Federation

\section{BANK ASSURANCE AND PROBLEMS OF ITS DEVELOPMENT IN RUSSIA AND FOREIGN COUNTRIES}

\begin{abstract}
Economic crisis and worsening of the microeconomic situation have a negative effect on major indices of banking and insurance activities. In the national financial science a steady opinion prevailed that the main objective of insurance is cutting risks and minimization of possible losses in the sphere of socio-economic relations on the basis of financial protection. Anyhow, theoretical and practical investigations prove that the role of insurance is much wider and the synergetic effect from positive processes on the insurance and banking markets impose an influence on accelerated and stabilizing development of other economic sectors. The interpenetration of the banking and insurance businesses during the last ten years has been a dominant tendency on the financial market, which has shaped the prerequisites for considering and analyzing such a phenomenon as banking assurance. The article considers approaches to defining the term «bank assurance». It shows the practice of use and development level for bank assurance both in Russia and abroad. It gives an analysis of the world bank assurance market and identifies the problems of its development.
\end{abstract}

Keywords. Insurance; bank assurance; banks; insurance organizations; credit insurance; economic crisis.

Article info. Received March 30, 2015; accepted April 14, 2015; available online May 5, 2015. 
В экономической литературе имеет место много определений понятия «банкострахование» (англ. bancassurance) $[5 ; 7 ; 10 ; 14]$, однако, этот термин до сих пор не является привычным и понятным для многих участников рынка. При этом и страховщики, и банкиры давно на практике определились с преимуществами совместной работы этих финансовых институтов ${ }^{1}$.

История возникновения банкострахования началась во Франции в 70-е гг. прошлого столетия, где на тот период сложился очень зрелый и конкурентный рынок в банковском секторе и это позволило впервые начать активное внедрение концепции банкострахования. Рост стройиндустрии вызвал спрос граждан к жилищному кредитованию, что провоцировало банки объединить ипотечное кредитование со страхованием определенных рисков в этой сфере. Банки предложили свои каналы продаж, что резко позволило снизить затраты страховщиков на дистрибуцию (от 30 до 50 \% ). Интенсивное развитие накопительного страхования жизни усилило этот процесс. Используя существующее законодательство в страховании, банкострахование обеспечивал банкам новые источники прибыли, а страховым организациям рост страховых портфелей. Этот канал продаж позволил оптимизировать выбор банковского и страхового продукта, что увеличивало лояльность клиента. Потребителям предоставлялся выбор в одном месте любого из финансовых инструментов: получение краткосрочной ссуды, планирование покупки недвижимости и иного имущества, выбор вида пенсионного обеспечения, защита против непредвиденных неблагоприятных обстоятельств. Сокращение затрат страховщиков на дистрибуцию через банковские каналы позволили существенно снизить размеры страховой премии для клиентов. Также проводилась разработка новых страховых продуктов, с целью удовлетворения потребностей клиентов, которые были бы недоступны для них, если бы банки и страховщики работали независимо ${ }^{2}$.

В странах Западной Европы и США банкострахование представляет собой вторжение коммерческих банков в сферу страхования (преимущественно личного страхования) и выражается в приобретении уже функционирующих страховых компаний или (если это разрешено законодательством) организации системы продажи полисов через разветвленную сеть банковских филиалов и отделений. Развитие банкострахования отражает концепцию роли коммерческого банка для частной клиентуры, как «финансового супермаркета», где каждый клиент может удовлетворить как потребности в банковском обслуживании (текущем счете, накопительном вкладе, обмене валюты и т. д.) и в финансовом консалтинге, так и страховой интерес. Формой банкострахования является создание банковских трастов. Банкострахование способствует улучшению банковской ликвидности и отражает тенденцию к универсализации банковской деятельности в индустриально-развитых странах, усиливает конкуренцию на страховом рынке [1; 12].

В настоящее время в российской финансовой науке и практике банкострахование получил теоретическое развитие и стал активно применяется на практике ${ }^{3}$. Анализ понятий термина «банкострахование» показывает, что общим признаком в этих определениях является то, что он означает «продажу страховых продуктов с использованием банковских каналов» [6]. Однако этот термин можно отнести не только к продажам, поскольку ряд его особенностей (юридические, финансовые, культурные и поведенческие аспекты) интегрально фор-

${ }^{1}$ Иногда термин «банкострахование» (банкассуранс, банкассюранс) - страхование, проводимое коммерческими банками (кроме страхования банковских депозитов).

${ }^{2} \mathrm{~K}$ таким продуктам, например, можно было отнести страхование на случай овердрафта по текущему счету, страхование депозитов и другие страховые продукты. Появилась удобная для клиента возможность оплаты страховой премии с помощью карточек АТМ, аналогично получению кредита и погашению задолженности за кредит.

${ }^{3}$ Единственное издание, которое полноценно освещает вопросы банкострахования в России это журнал «Банки \& страховые компании» информационно-консалтинговой группы «Биз-

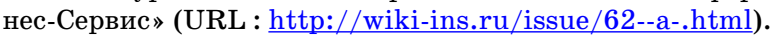


мируют концепцию банкострахования. В различных государствах перечисленные характеристики вносят в данную концепцию определенные изменения ${ }^{1}$.

По мнению экспертов финансового рынка,_наиболее критичным фактором успеха развития банкострахования является законодательная база конкретной страны ${ }^{2}$. В некоторых государствах финансовые и налоговые преимущества способствовали активному развитию программ накопительного страхования жизни, как, например, это было во Франции, что позволило ей стать лидером в этом секторе страхования в Европе.

Модель банкострахования предполагает организацию единых бизнес-процессов, наличие объединенной информационной системы, обучение и вознаграждение продавцов за фактически проданные страховые продукты. Информационная система, которая полностью внедряет страховую практику в банковскую культуру, является необходимым условием. Это позволяет участникам децентрализовать процесс андеррайтинга и внедрить его в максимально возможной степени в банковский процесс, с одновременной централизацией учета полисов и управления страховыми событиями в страховой организации. Успешная совместная стратегия маркетинга способствует обучению штата банковских работников, а также повышению их мотивации, с целью обеспечения совместной продажи страховых продуктов и получения дополнительных источников доходов.

Страховая деятельность в банковской сети часто начинается с продуктов, которые связанны с банковской деятельностью, например, программ индивидуального страхования жизни, страхования кредитных и банковских сделок (страхование залогового имущества, потребительского кредитования, кредитных карточек). Продавая продукты по страхованию жизни, банки увеличивали свою долю активов с длительным сроком применения. При продаже продуктов страхования кредитных и банковских сделок, банками предлагался дополнительный сервис клиентам. Это обеспечивало им свободный доступ к страховым продуктам, простой метод оплаты и выгодное финансовое покрытие. Также абсолютно необходимым условием является приспособленность страховых продуктов к банковской сети, т. е. они должны быть простыми в андеррайтинге, а также легкими для понимания как клиентам, так и продавцам.

На сегодняшний день, понятие «банкострахование» является дискуссионным вопросом и имеет широкое смысловое наполнение и в теоретическом, и в практическом аспектах. Таким образом, «банкострахование» - продажа страховых услуг, в основном программ страхования жизни, через банковские каналы; предоставление больших полномочий по контролю над финансовым сектором экономики государства создание единой информационной системы банков и страховых организаций, обучение и мотивация работников; оказание давления на клиентов путем навязывания контракта по страхованию жизни заемщика при ипотечном кредитовании, автокредитовании и по ряду других банковских программ.

В России на протяжении последних лет наблюдается тенденция поэтапного процесса интеграции банков и страховых организаций, синтез их услуг с целью реализации как банковских, так и страховых продуктов. Обе стороны совмеща-

${ }^{1}$ URL : $\underline{\text { http://cbs.org.ua/wp-content/uploads/2010/10/present. }}$

${ }^{2}$ В Италии (после принятия закона Амато (Amato), позволившего банкам вкладывать капитал в страховые компании) национальные регуляторные правила 1990 г. сыграли ключевую роль. В США аналогичный законопроект Гласса-Стигалла (Glass-Steagall Act) был отменен только 12 ноября 1999 г., который до этого запрещал банкам заниматься инвестиционной и страховой деятельностью (например, Citibank, объединившись со страховой компанией Travelers Group, coздал корпорацию Citigroup, объединяющую банковские и страховые услуги). В некоторых странаx bancassurance все еще в значительной степени запрещается. В Таиланде до недавнего времени, страховым компаниям не разрешалось выплачивать комиссионные банкам. В Германии, Великобритании, США и Канаде страховой рынок в значительной степени находился в руках брокеров. Благодаря этому, а также существующим некоторым регуляторным ограничениям банки не смог-

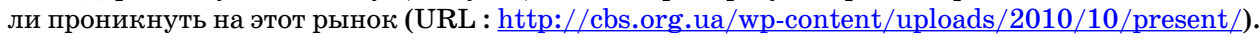


ют каналы продаж и клиентские базы, а также открывают доступ к внутренним финансовым ресурсам друг друга, благодаря чему повышается эффективность деятельности обоих секторов экономики. Взаимодействие страховых компаний и банков по данному направлению является взаимовыгодным сотрудничеством, поскольку позволяет осуществить диверсификацию услуг и каналов распределения, минимизировать риски и повысить надежность всех финансовых операций. Банки традиционно страхуют отдельные операционные риски, практически не используя комплексное страхование, которое является обязательным за рубежом. Данный вид комплексного страхования позволяет защитить значительную часть рисков, возникающих в банковской деятельности, а, следовательно, является важной составляющей комплексной системы риск-менеджмента любого банка, ориентирующегося на долгосрочное и устойчивое развитие. Для российского банкострахования это актуальные вопросы ближайшего развития, после снижения экономической напряженности.

Процесс банкострахования учитывает максимальные выгоды и минимальные риски всех участников отношений - клиентов, банков и страховых компаний (рис. 1). Первые получают уверенность в качестве предоставляемой услуги, им предлагается полный набор услуг с минимальной потерей времени и максимальной выгодой и комфортом. Кроме того, приобретая страховые продукты через филиальную сеть банков, клиенты обретают возможность получить страховые услуги в совокупности с банковскими и по цене ниже, чем если бы приобретали их в страховой компании. Вторые заинтересованы в увеличении комиссионного дохода, расширении клиентской базы и уменьшении финансовых рисков, связанных с потерей трудоспособности заемщиков, мошеннических операций по кредитным и дебитным картам клиентов и т. д. Третьи - в расширении рынка сбыта, росте страховых премий и качества портфеля, а, следовательно, увеличении доходов и прибыли.

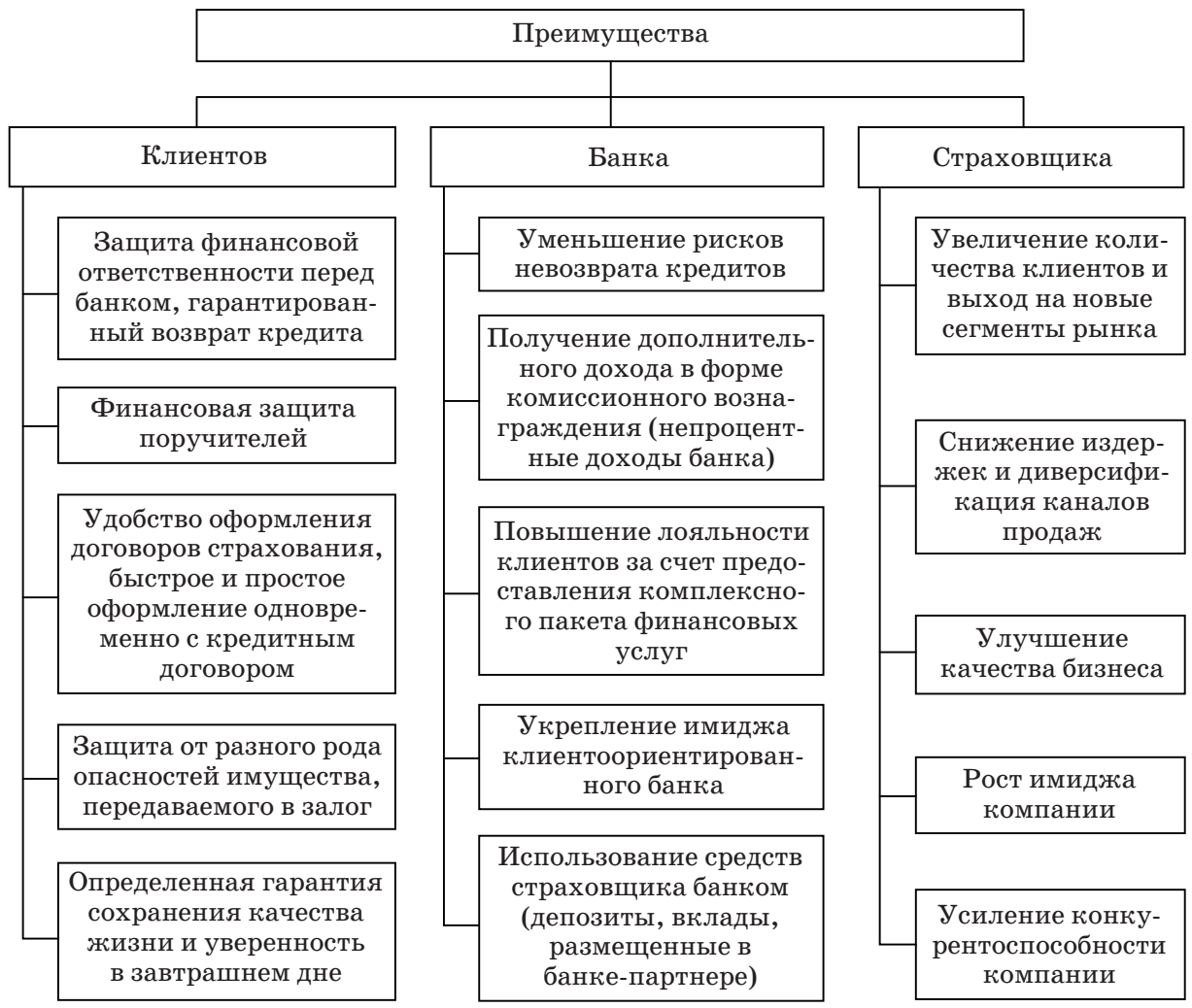


До последних кризисных явлений в экономике отмечался рост объемов кредитования малого и среднего бизнеса и, как следствие, увеличивались объемы страхования жизни заемщиков, залогов и имущества, поскольку рост этого сегмента страхования лимитирован только ростом кредитования [11]. Также популярным было страхование держателей банковских карт, запросы по которому растут в геометрической прогрессии.

Анализ данных в России показывает снижение темпов прироста и рост дальнейшей концентрации рынка банкострахования (рис. 2-4)․

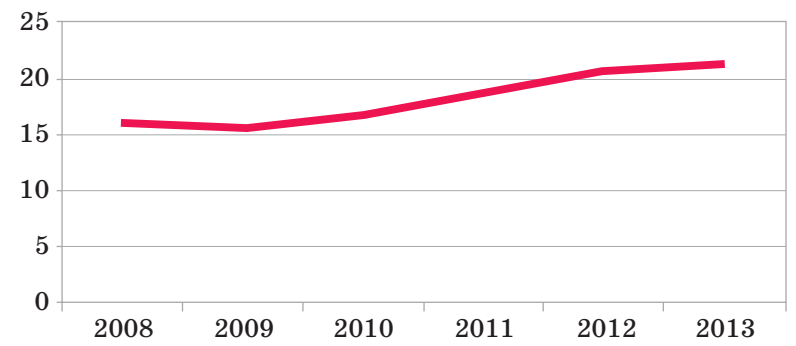

Рис. 2. Динамика доли банкострахования в общем объеме страхового рынка России (без учета обязательного медицинского страхования) за 2008-2013 г2., \% Источник: [17]

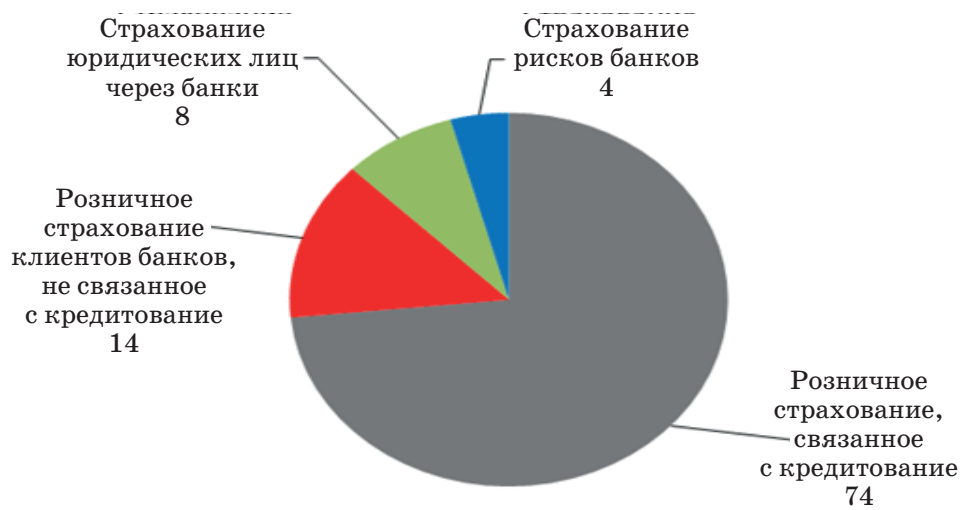

Рис. 3.Структура банкострахования в России в 2013 г., \% Источник: [17]

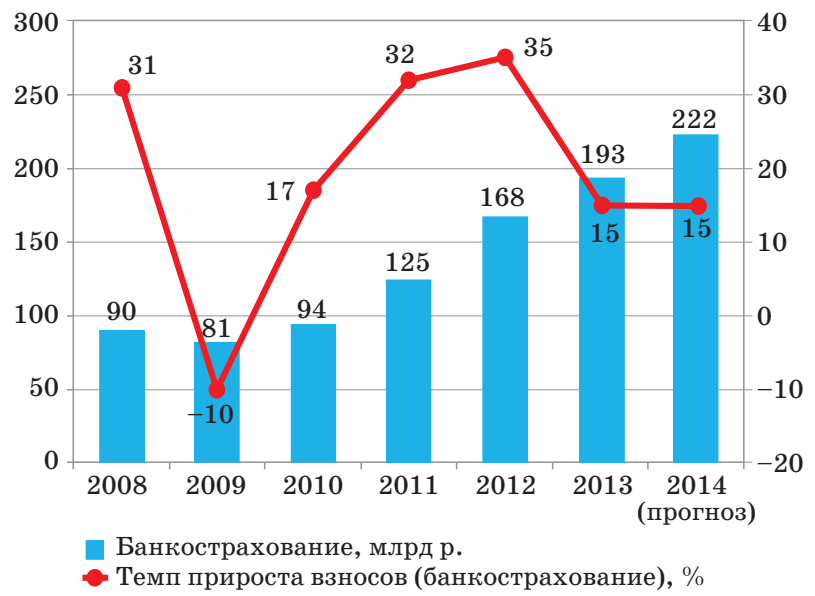

Рис. 4. Динамика рынка банкострахования в России 2008-2014 г2. Источник: [17]

${ }^{1}$ Использованы материалы «Эксперт РА». 
По результатам исследований основной рост рынка банкострахования обеспечили кэптивные страховщики за счет страхования при потребительском кредитовании. Это связано с высокой активностью страховых организаций, входящих в одну группу с банками. В 2012-2013 гг. доля кэптивных страховщиков в банкостраховании составила $37 \%$ и 44 \% соответственно. По прогнозам «Эксперт РА» в 2013 г. доля кэптивных страховщиков должна была вырасти до 50 \%, однако среди лидеров банкострахования произошли существенные изменения. Доля десяти крупнейших страховщиков в банкостраховании составила 64 \% за 2013 г., что на семь процентных пунктов выше 2012 г. (табл. 1).

Таблица 1

Топ-10 рынка банкострахования в России на 1 января 20142.

\begin{tabular}{|c|c|l|r|r|}
\hline \multicolumn{2}{|c|}{$\begin{array}{c}\text { Место } \\
\text { в рейтине }\end{array}$} & \multicolumn{1}{|c|}{ Компания/группа компаний } & $\begin{array}{c}\text { Страховые } \\
\text { взносы, } \\
\text { тыс. p. }\end{array}$ & $\begin{array}{c}\text { Темпы } \\
\text { прироста } \\
\text { взоосов, \% }\end{array}$ \\
\cline { 1 - 4 } 2012 г. & 2013 г. & & 21592489 & 371,4 \\
\hline 13 & 1 & Группа Ренессанс & 17508631 & 84,0 \\
\hline 8 & 2 & Страховая группа «Альфастрахование» & 16952559 & 58,6 \\
\hline 4 & 3 & ООО Страховая компания «ВТБ Страхование» & 8,4 \\
\hline 3 & 4 & Страховое открытое акционерное общество «ВСК» & 13161628 & 10,5 \\
\hline 6 & 5 & ООО Страховая компания «Согласие» & 11875661 & 14,5 \\
\hline 5 & 6 & $\begin{array}{l}\text { Открытое страховое акционерное общество } \\
\text { «РЕО-Гарантия» }\end{array}$ & 11420942 & 11,7 \\
\hline 7 & 7 & Группа страховых компаний «Русский Стандарт» & 9611918 & -119 \\
\hline 41 & 8 & ООО Страховая компания «Сбербанк страхование» & 9028822 & 10519,0 \\
\hline 9 & 9 & Страховая группа «СОГАЗ» & 8086084 & 59,1 \\
\hline 10 & 10 & Группа Альянс & 6503421 & 76,0 \\
\hline
\end{tabular}

Источник: [13].

Лидером рынка банкострахования в 2013 г. стала страховая группа «Группа Ренессанс» ${ }^{1}$, не имеющая аффилированного банка, которая переместилась с 13-го места на 1-е. Страховые взносы группы выросли на 371,4 \% , а доля составила $11 \%$.

Кроме этого, другие рыночные страховщики также не сбавили темпов прироста взносов, что позволило им сохранить позиции 2012 г. Среди страховых компаний, имеющих аффилированные банки, значительный прирост взносов показали Страховая группа «Альфастрахование», которая в 2013 г. увеличила взносы по банкострахованию на 84 \%, что позволило ей переместиться с 8-го места на 2-е, и ООО Страховая компания «Сбербанк страхование», она переместилась с 41-го места на 8-е. Розничное банкострахование, связанное с кредитованием, увеличилось за 2013 г. на 7 \%, что было связано с разнонаправленной динамикой прироста взносов двух крупнейших видов: страхования автокаско при автокредитовании и страхования жизни и здоровья при потребкредитовании [13].

В конце 2014 начале 2015 гг. из-за резкого снижения кредитования населения самый доходный (как для банков, так и для страховщиков) сегмент рынка - кредитное страхование - сократился примерно на 45 \% от общего объема сборов, заняв впервые за последние пять лет менее половины рынка. Финансовые показатели компаний, чья деятельность базировалась только на кредитном страховании, резко упали, что привело к смене лидеров на рын-

${ }^{1}$ Группа Ренессанс, включает компании ООО «Группа Ренессанс Страхование» и ООО «СК «РЕНЕССАНС ЖИЗНЬ». 
ке страхования жизни ${ }^{1}$. На текущий момент в сфере страхования жизни нет механизма компенсационных фондов, что является серьезной проблемой для проработки будущего ускоренного развития отрасли.

Следует отметить важность развития именно не связанных с кредитами продуктов, особенно долгосрочных, которые служат источником «длинных денег» для экономики страны. Снижение роли кредитного страхования является поводом активного развития других стратегий. По мнению экспертов страхового рынка, «эффект уменьшения доли «кредитки» тактически негативный, но стратегически - позитивный» [16]. Хотя кредитное страхование считается необходимым направлением, качество развития рынка все же оцениваю по приросту долгосрочных видов.

В 2013 г. крупнейшим видом розничного банкострахования, связанного с кредитованием, впервые стало страхование жизни и здоровья заемщиков при потребкредитовании. Его объем составил 71,8 млрд р., а прирост взносов $45 \%$. Причинами роста этого вида банкострахования оставался рост потребительского кредитования и желание банков получать высокие комиссионные вознаграждения. Уступив место страхованию заемщиков потребкредитов, страхование автокаско при автокредитовании стало вторым в розничном банкостраховании. В 2013 г. взносы по этому виду сократились на 33 \% и составили 40 млрд р., что связано с тем, что с 2013 г. перестали учитываться в качестве банкострахования взносы по автострахованию при автокредитовании, полученные через дилерский канал [2].

За 2013 г. в условиях замедления темпов прироста ипотечного рынка, а также заметного упрощения условий кредитования произошло сокращение ипотечного страхования на $6 \%$, его объем составил 12,8 млрд р. [2]. Ранее ипотечное страхование было достаточно обременительным для заемщика, так как могло включать в себя сразу несколько видов страхования: титул, залог, жизнь заемщика, ответственность за непогашение кредита. Теперь же большинство банков пошло на упрощение условий кредитования и готово принимать один вид ипотечного страхования.

В 2012 г. объем рынка банкострахования составил 161 млрд р., что на 28 \% выше показателя прошлого года (аналитики «Эксперт РА» прогнозировали прирост 30 \% ). В 2013 г. темпы роста банкострахования замедлились и составили $20 \%$, а рост рынка по-прежнему обеспечивал страхование жизни и здоровья заемщиков при потребительских кредитах. Если драйвером и основой рынка банкострахования прошлых лет было страхование каско (в настоящее время переходит в дилерский канал продаж) - автомобилей, приобретаемых в кредит, то в 2013 г. - страхование жизни и здоровья заемщиков при потребительском кредитовании, его прирост составил 50 \%. Некэптивные страховщики смогли найти свою нишу на рынке банкострахования в страховании собственных рисков банков, страховании юридических лиц, продвижении коробочных продуктов [2].

Высокими темпами растет страхование собственных рисков банков: страхование эмитентов банковских карт, прирост в 2013 г. составил 100 \%, страхование ответственности персонала и D\&O (ответственности органов управле-

\footnotetext{
${ }^{1}$ Все компании уходили интеллигентно (например, Fortis и ING), которые передавали портфели, не ущемляя интересов клиентов. В 2015 г. произошел первый «плохой» уход с рынка ОСЖ «Россия». Прежде. Сейчас среди первых 10 страховщиков жизни пять - иностранные компании. Вряд ли они уйдут с нашего рынка из-за финансовых результатов - убыточность в сегменте не носит того критического характера, как в некоторых сегментах общего страхования. Надеюсь, что иностранные игроки, которые обогащают наш рынок технологиями, знаниями и экспертизой, продолжат работать, несмотря на ухудшение взаимоотношений России и Запада.
} 
ния) - $30 \%$, ВВВ (комплексное страхование рисков банков) $-25 \%{ }^{1}$. Темп прироста взносов в страховании залогового имущества юридических лиц замедлился и составят 7 \% , что связано с ростом доли беззалогового кредитования [15]. Тем не менее, в этом сегменте продолжают доминировать рыночные страховые компании. Еще одно перспективное для рыночных страховщиков направление сотрудничества, в котором особенно заинтересованы средние и небольшие банки - продажа в отделениях банков «коробочных» страховых продуктов, не связанных с банковскими услугами.

Новым импульсом развития рынка банкострахования в 2013-2014 гг. становится накопительное и инвестиционное страхование жизни, которое невозможно навязать клиентам. Здесь необходимы особые маркетинговые технологии продаж, которыми обладают классические страховщики жизни. По оценке «Эксперт РА», лишь крайне небольшое число крупнейших банков смогут развить это направление силами собственных страховых компаний.

Несмотря на оживление кредитования, страхование залогового имущества юридических лиц стагнирует, и продолжает сокращаться. Причина повышение доли беззалогового кредитования и замена залогового на другие виды обеспечения. Увеличивается страхование малого и среднего бизнеса при кредитовании.

Исходя из сложившейся экономической ситуации, объемы кредитного страхования в 2015 г. снизятся, поскольку «рухнул» авторынок, и существенно снизились объемы ипотечных кредитов. Накопительное и инвестиционное страхование будут расти и на фоне кризиса, потому что все большее число банков готовы предлагать их клиентам в рамках персонального финансового планирования. Развитие накопительного страхования также поддержат налоговые льготы по НДФЛ, введенные в этом году [16].

Практика применения банкострахования в зарубежных странах показывает, что более 10 лет эти каналы являлись лидирующими (табл. 2).

Таблица 2 Доля каналов дистрибуции страховых услуг в ряде зарубежных стран, \%

\begin{tabular}{|l|r|r|r|r|r|r|r|r|r|}
\hline $\begin{array}{c}\text { Каналы дистри- } \\
\text { буции }\end{array}$ & $\begin{array}{c}\text { Фран- } \\
\text { ция }\end{array}$ & $\begin{array}{c}\text { Испа- } \\
\text { ния }\end{array}$ & Италия & Бельгия & $\begin{array}{c}\text { Велико- } \\
\text { британия }\end{array}$ & $\begin{array}{c}\text { Гер- } \\
\text { мания }\end{array}$ & США & Канада & $\begin{array}{c}\text { Порту- } \\
\text { галия }\end{array}$ \\
\hline Банковские & 62 & 72 & 63 & 56 & 12 & 17 & 10 & 0 & 82 \\
\hline Традиционные & 32 & 21 & 28 & 30 & 86 & 77 & 90 & 0 & 10 \\
\hline Прямые продажи & 6 & 7 & 9 & 14 & 2 & 6 & 0 & 0 & 8 \\
\hline
\end{tabular}

Источник: Source: The Insurance Argus. 2002. 12 April. URL : http://www.bankforward.ru/ bfos-617-3.html.

За последние десятилетия было создано много международных, чаще европейских, альянсов между банками и страховыми компаниями. Если на начальных этапах банкострахование было достаточно фрагментированным, то слияния привело к высокой концентрации банковского и страхового капиталов. Во Франции в начале века по каналам банкострахования собиралось 35 \% всех премий по страхованию жизни; 60 \% премий по накопительному страхованию; 7 \% по имущественному страхованию и 69 \% премий по индивидуальным накоплениям [12].

На испанском рынке банкострахование развивалось более быстрыми темпами из-за хорошо организованной сети региональных строительных компаний. Объем банкострахования составил более 65 \% премий по страхованию жизни (приблизительно 17 млрд евро в 2001 г.), по сравнению с 43 \% в 1992 г. Однако темпы роста зависели не только от внедрения банкострахования, но и от динамики его состояния (страхование жизни в течение последних 15 лет

1 Банкострахование: замкнутый рынок. URL : http://rf-club.ru/researches/insurance/ bancassurance_2012. 
имело среднегодовой рост $30 \%$ ). Через банкострахование в настоящее время поступают 50 \% премий по страхованию жизни [3; 8].

Банкострахование в Португалии имело самую высокую степень проникновения - $82 \%$ рыночной доли, что составляет около 4 млрд евро премий по рынку страхования жизни по программам Term Life [8; 9].

В Италии темпы роста банкострахования увеличились после принятия закона Амато, что, вместе с благоприятным налогообложением (1995-1998 гг.) еще сильнее продвинуло продукты по страхованию жизни. Существенным фактором в развитии банкострахования явилось наличие хорошо организованной банковской сети в сочетании с Итальянским общественным трастом при банках. В результате, рыночная доля банкострахования увеличилась с $8 \%$ в 1992 г. до $50 \%$ в 2002 г., представляя более $60 \%$ нового бизнеса по страхованию жизни, в том числе более 70 \% по накопительному страхованию жизни (программамы Unit Linked или Index Linked) [9].

В Бельгии банкострахование получило значительное развитие в последние годы в основном на рынке страхования жизни, при этом значительное количество полисов продавалось брокерами. Причиной интенсивного развития стали инвестиции, осуществленные иностранными компаниями. Также были использованы преимущества развития страхования жизни, имеющие высокие темпы роста. Кроме того, существенную роль оказал процесс слияния банков и страховщиков и их реструктуризация, в итоге на рынке появилось пять лидеров. При 56 \% рыночной доли на рынке страхования жизни банкострахование стало лидером индивидуального страхования (35\% , за исключением программы Unit linked) и балансом между накопительными программами страхования и программами страхования от несчастного случая. Таким образом, в Европе банкострахование сводилось к продаже страховых продуктов по страхованию жизни через банковские каналы $[8 ; 12]$.

В Великобритании, Германии, США и Канаде концепция банкострахование не получила такого широкого развития и поддержки как в других странах, что связано с сильным законодательством, препятствующим получению банками контроля над всем финансовым рынком. Кроме того, наличие сильного рынка посредников (брокеров), сформировало высокую степень доверия у потребителей. Деятельность брокера возможна при наличии, во-первых, полиса обязательного страхования своей профессиональной ответственности и, во-вторых, персональной ответственности перед клиентом за данные рекомендации при размещении его рисков.

Общей проблемой в банкостраховании для всех рассмотренных стран, включая Россию, является вмененное страхование или навязывание страховых услуг при приобретении банковских продуктов. Так, в проекте директивы Европарламента по страховым посредникам в статье по банкострахованию, а также в регуляторной статье, отмечено о запрете навязывания страховых услуг при приобретении банковских продуктов [3; 4].

«Финансовым учреждениям, работающим в области банкострахования, запрещено без соответствующего письменного согласия клиента:

1. Использовать частную информацию клиентов при заключении им любого страхового контракта, платежи по которым осуществлялись через счета финансового учреждения, с целью реализации определенных предложений к ним относительно страховых продуктов, которые они распределяют.

2. Требовать от клиента финансового учреждения приобретения страхового продукта, распределяемого последним, как условия для покупки финансового продукта из его обычного ряда.

При нарушениях этих запретительных мер необходимо применять санкции к соответствующим финансовым учреждениям» (Цит. по : [4]). 
В России с начала 2015 г. по данным Федеральной антимонопольной службы (ФАС), число жалоб на навязывание страховок при выдаче кредита стало увеличиваться. Потребителям зачастую не предоставляют бланк, в котором они могли бы зафиксировать отказ от страховки, либо отказывают в выдаче кредита из-за нежелания клиента страховаться. В связи с этим ФАС планирует внести в законодательство ряд изменений ${ }^{1}$ и ввести штрафы для банков, навязывающих страховку. Размер штрафа планируется установить на уровне 50 тыс. р. для должностных лиц и до 500 тыс. р. для юридических лиц ${ }^{2}$.

Банки, как и страховые организации, заинтересованы в сотрудничестве, поскольку данное партнерство позволяет им привлекать свободные денежные средства страховых компаний и защищать себя от всевозможных рисков, связанных с кредитованием, поэтому банкострахование получит дальнейшее развитие.

\section{Список использованной литературы}

1. Андреева Е. В. Особенности российской системы страхования вкладов / Е. В. Андреева // Страховое дело. - 2006. - № 2. - С. 17-20.

2. Будущее страхового рынка: временная передышка : обзор / подгот. : Н. Данзурун, О. Басова, О. Скуратова [и др.]. - M., 2014. - 80 с. - URL : http://raexpert.ru/ docbank/a62/9d2/923/3ce240a22fdcce552488776.pdf.

3. Габидулин И. А. Bancassurance по-эсэнгевски / И. А. Габидулин, В. Н. Лушниченко // Мир денег. - 2007. - № 8 (86). - С. 54-59.

4. Габидулин И. А. Bancassurance: за и против / И. А. Габидулин. - URL : http:// pandia.ru/text/77/193/33823.php.

5. Донецкова О. Ю. Банкострахование : учебник / О. Ю. Донецкова, Е. А. Помогаева. - М. : Директ-Медио, 2013. - 310 с.

6. Жигас М. Г. Развитие коммерческого страхования в постцентрализованной экономике : автореф. дис. ... д-ра экон. наук / М. Г. ЖКигас. - Екатеринбург, 2007. - 34 с.

7. Жигас М. Г. Развитие страховой защиты и финансово-экономические особенности страховой деятельности / М. Г. ЖКигас // Известия Иркутской государственной экономической академии. - 2014. - № 4 (96). - С. 28-39.

8. Ивакина А. В. Комбинация банковской и страховой деятельности: зарубежный опыт и особенности в Украине / А. В. Ивакина // Бизнес Информ. - 2011. — № 10. C. $123-125$.

9. Ивакина А. В. Применение комбинаций банковской и страховой деятельности на основе зарубежного опыта / А. В. Ивакина // Проблемы формирования новой экономики XXI века : материалы III Междунар. науч.-практ. конф. 23-24 дек. 2010 г. - URL : http://www.confcontact.com/20101224/2 ivakina.php.

10. Макейкина С. М. Банкострахование в России: современные тенденции и перспективы развития / С. М. Макейкина, А. В. Екимов // Системное управление. - 2012. № 1 (14). — URL : http://sisupr.mrsu.ru/2012-1/PDF/3_Strah/Ekimov\% 201.pdf.

11. Оношко О. Ю. Управление банковским кредитованием субъектов малого и среднего предпринимательства в России: исследование тенденций развития / О. Ю. Оношко, В. Ю. Далбаева / У Уравление экономикой: методы, модели, технологии : материалы четырнадцатой междунар. науч. конф. Уфа, Красноусольск, 9-11 окт. 2014 г. - Уфа : Изд-во Уфим. гос. авиац. техн. ун-та, 2014. - С. 39-45.

12. Пашкова Е. Н. Зарубежный и российский опыт развития банковского страхования / Е. Н. Пашкова // Экономика и управление: анализ тенденций и перспектив развития. - 2013. - № 8. - С. 196-202.

13. Рынок банкострахования в 2013 году: ставка на жизнь : обзор / подгот. О. Басова, А. Янин. - M., 2014. - 51 c. - URL : http://raexpert.ru/docbank/1c7/f5d/ $\underline{\mathrm{f} 88 / 50 \mathrm{c} 8 \mathrm{a} 62 \mathrm{~d} 821 \mathrm{af} 69 \mathrm{bb} 8 \mathrm{c} 954 \mathrm{~d} . \mathrm{pdf} .}$

\footnotetext{
${ }^{1} \mathrm{~B}$ настоящее время закон «О потребительском кредите» обязывает банкиров предоставлять заемщику возможность отказаться от страховки, но не закрепляет ответственности за навязывание страховых продуктов. Соответствующей статьи нет и в КоАП (в отличие от навязывания дополнительных услуг при страховании, ст. 15.34.1).

2 ФАС намерена штрафовать банки за навязывание страховки при выдаче кредита. URL : http://www.dp.ru/a/2015/03/23/FAS_namerena_shtrafovat_b/.
} 
14. Страхование : учебник / под ред. Т. А. Федоровой. - 3-е изд., перераб. и доп. М. : Магистр, 2009. -1006 с.

15. Тарханова Е. А. Страхование банковских кредитных рисков в коммерческом банке / Е. А. Тарханова, А. В. Пастухова // Молодой ученый. - 2014. - № 5. C. 321-323.

16. Чернин М. Страховщикам придется искать замену кредитному страхованию : интервью / Максим Чернин : беседовала Л. Коваль // Ведомости. - 2015. - 21 апр. URL : http://www.vedomosti.ru/finance/characters/2015/04/21/strahovschikampridetsya-iskat-zamenu-kreditnomu-strahovaniyu-schitaet-maksim-chernin.

17. Юргенс И. Ю. Страховой рынок в 2014 году: вызовы и перспективы / И. Ю. Юргенс. — URL : http://www.insur-info.ru/analysis/953/.

\section{References}

1. Andreeva E. V. Features of the Russian deposit insurance system. Strakhovoe delo= Insurance, 2006, no 2, pp. 17-20. (In Russian).

2. Danzurun N., Basova O., Skuratova O. et. al. Budushchee strakhovogo ryn-ka: vremennaya peredyshka : obzor [Future of insurance market: a temporary respite : a review]. Moscow, 2014. 80 p. Available at: http://raexpert.ru/docbank/a62/9d2/923/3c e240a22fdcce552488776.pdf. (In Russian).

3. Gabidulin I. A., Lushnichenko V. N. Bank assurance a la CIS. Mir deneg $=$ World of Money, 2007, no. 8 (86), pp. 54-59. (In Russian).

4. Gabidulin I. A. Bancassurance: $z a$ i protiv [Bank assurance: pro and contra]. Available at: http://pandia.ru/text/77/193/33823.php. (In Russian).

5. Donetskova O. Yu., Pomogaeva. E. A. Bankostrakhovanie [Bank Assurance]. Moscow, Direkt-Medio Publ., 2013. 310 p.

6. Zhigas M. G. Razvitie kommercheskogo strakhovaniya $v$ posttsentralizo-vannoi ekonomike. Avtoref. Dokt. Diss. [Development of commercial insurance in the postcentralized economy. Doct. Diss. Thesis]. Ekaterinburg, 2007. 34 p.

7. Zhigas M. G. Development of insurance protection and financial and economic features of insurance activity. Izvestiya Irkutskoi gosudarstvennoi ekonomicheskoi akademii = Izvestiya of Irkutsk State Academy of Economics, 2014, no. 4 (96), pp. 28-39. (In Russian).

8. Ivakina A. V. Combination of banking and insurance activities: foreign experience and features in Ukraine. Biznes Inform = Business Inform, 2011, no. 10, pp. 123-125. (In Russian).

9. Ivakina A. V. Application of combinations of banking and insurance activities on the basis of foreign experience. Problemy formirovaniya novoi ekonomiki XXI veka. Materialy III Mezhdunarodnoi nauchno-prakticheskoi konferentsii.23-24 dekabrya 2010 g. [Problems of forming new economy of XXI century. Materials of the 3rd International Research Conference, Dec. 23-24. 2010]. Available at: http://www.confcontact.com/20101224/2 ivakina.php. (In Russian).

10. Makeikina S. M., Ekimov A. V. Bank assurance in Russia: current tendencies and development prospects. Sistemnoe upravlenie $=$ Systemic Management, 2012, no. 1 (14). Available at: http://sisupr.mrsu.ru/2012-1/PDF/3 Strah/Ekimov\% 201.pdf. (In Russian).

11. Onoshko O. Yu., Dalbaeyva V. Yu. Management of banking crediting of small and medium-sized business entities in Russia: investigation of tendency development. Upravlenie ekonomikoi: metody, modeli, tekhnologii. Materialy chetyrnadtsatoi mezhdunarodnoi nauchnoi konferentsii, Ufa, Krasno-usol'sk, 9-11 oktyabrya $2014 \mathrm{~g}$. [Manageent of economy: methods, models, technologies. Materials of the 14th International Science Conference, Ufa, Krasnousol'sk, 9-11 October 2014]. Ufa State Aviation Technical University Publ., 2014, pp. 39-45. (In Russian).

12. Pashkova E. N. Foreign and Russian experience of bank assurance development. Ekonomika $i$ upravlenie: analiz tendentsii $i$ perspektiv razvitiya $=$ Economics and Management: analysis of tendencies and prospects of development, 2013, no. 8, pp. 196-202. (In Russian).

13. Basova O., Yanin A. (eds). Rynok bankostrakhovaniya v 2013 godu: stavka na $z$ hizn' [Bank assurance market in 2013: stake on life]. Moscow, 2014. 51 p. Available at: http://raexpert.ru/docbank/1c7/f5d/f88/50c8a62d821af69bb8c954d.pdf. 
14. Fedorova T. A. (ed.). Strakhovanie [Insurance]. $3^{\text {rd }}$ ed. Moscow, Magistr Publ., 2009.1006 p. (In Russian).

15. Tarkhanova E. A., Pastukhova A. V. Insurance of banking credit risks in commercial banks. Molodoi uchenyi = Young Scientist, 2014, no. 5, pp. 321-323. (In Russian).

16. Chernin M. Insurers will have to seek replacement for credit insurance: an interview. Vedomosti = Journal, 2015, 21 anp. Available at: http://www.vedomosti.ru/ finance/characters/2015/04/21/strahovschikam-pridetsya-iskat-zamenu-kreditnomustrahovaniyu-schitaet-maksim-chernin.

17. Yurgens I. Yu. Strakhovoi rynok v 2014 godu: vyzovy i perspektivy [Insurance market in 2014: challenges and prospects]. Available at: http://www.insur-info.ru/ analysis $/ 953 /$. (In Russian).

\section{Информация об авторе}

Сарсенова Елена Геннадьевна - аспирант, кафедра страхования и управления рисками, Байкальский государственный университет экономики и права, 664003, г. Иркутск, ул. Ленина, 11, e-mail: zunya1990@mail.ru.

\section{Author}

Yelena G. Sarsenova - PhD Student, Chair of Insurance and Risk Management, Baikal State University of Economics and Law, 11 Lenin St., 664003, Irkutsk, Russian Federation; e-mail: zunya1990@mail.ru.

\section{Библиографическое описание статьи}

Сарсенова Е. Г. Банкострахование и проблемы его развития в России и зарубежных странах / Е. Г. Сарсенова // Известия Иркутской государственной экономической академии (Байкальский государственный университет экономики и права). - 2015. -

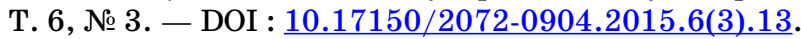

\section{Reference to article}

Sarsenova Ye. G. Bank assurance and problems of its development in Russia and foreign countries. Izvestiya Irkutskoy gosudarstvennoy ekonomicheskoy akademii (Baykalskiy gosudarstvennyy universitet ekonomiki $i$ prava) $=$ Izvestiya of Irkutsk State Economics Academy (Baikal State University of Economics and Law), 2015, vol. 6, no. 3. DOI: 10.17150/2072-0904.2015.6(3).13. (In Russian). 